\begin{abstract}
"Mircea cel Batran" Naval Academy Scientific Bulletin, Volume XIX - 2016 - Issue 1
Published by "Mircea cel Batran" Naval Academy Press, Constanta, Romania // The journal is indexed in:

PROQUEST / DOAJ / DRJI / JOURNAL INDEX / I2OR / SCIENCE LIBRARY INDEX / Google Scholar / Crossref /

Academic Keys / ROAD Open Access / OAJI / Academic Resources / Scientific Indexing Services / SCIPIO
\end{abstract}

\title{
WAYS TO STRENGTHEN THE COMMON EUROPEAN POLICY REGARDING MIGRATION AND ASYLUM
}

\author{
Mihaela Adina APOSTOLACHE ${ }^{1}$ \\ ${ }^{1}$ Assoc. Prof., PhD, Faculty of Letters and Sciences, Petroleum-Gas University of Ploiesti, Romania
}

\begin{abstract}
The paper addresses a topical issue that the European Union is facing, namely migration, which has become one of the most controversial phenomena, often associated with illegal activities, organized crime, terrorism or social and cultural tensions.

The aggravation of this phenomenon during 2015 has determined the effective management of the migration and asylum domains at Union level to be a primary objective for the current European executive (20142019). With May 2015, the European Commission adopted a new European Agenda on Migration, through which the EU proposes immediate action to meet current challenges of migration, and also medium and long-term initiatives to be taken in order to provide structural solutions for a better management of migration in all its aspects.

At the moment, the European Union and, therefore, all member states must rapidly find solutions for the refugees who reached the continent. This generates further debate at European level to find the most efficient ways to strengthen the common policy regarding migration and asylum.
\end{abstract}

Keywords: migration, European policy, refugee, asylum, international protection

\section{INTRODUCTION}

The aggravation of the migration phenomenon during 2015 generated a primary approach of the issue in the European Union, calling for the establishment of a set of basic measures, and also of a clear and coherent common policy in the field of migration and asylum.

The migration phenomenon has caused many European states to acquire a multiethnic character, including important communities of non-European immigrants. It is relevant that the legal/illegal migration has influenced the redefinition of the autonomy of nation-states and even the notion of "national identity" acquired a new connotation [1].

The large flows of migrants have led to the urgent need for better collective measures concerning the regulation of issues specific to migration. These measures aim at implementing the decisions on internal relocation, strengthening the security of external borders and the cooperation with countries of origin and transit.

\section{MIGRATION - NOTION AND ABSTRACTIONS}

A stricto sensu definition of migration is that this phenomenon represents the territorial movement/permutation of people, accompanied by a change of residence (from one country to another).

According to the Dictionary of the Romanian Language, we can speak of emigration when a person leaves the country of origin and settles, either permanently or temporarily, in another country. In this case, the verb "to emigrate" is synonymous with the verb "to expatriate".

The term immigration can be used when we change the perspective and look from the country

DOI: 10.21279/1454-864X-16-I1-057

(C) 2015. This work is licensed under the Creative Commons Attribution-Noncommercial-Share Alike 4.0 License. "of adoption" of a migrant. Immigration represents the action of a state to allow a foreign individual to enter its territory, with the intention of permanently settling there [2].

In a lato sensu analysis, migration considers both the move from the countries of origin to other countries in the case of large groups of people, and the effects arising at social, demographic, economic and cultural levels.

Migration is generated by a number of causes such as: war or other armed conflicts; natural disasters; hunger; epidemics; poverty; political corruption; political dissent; religious fundamentalism or intolerance; deplorable economic conditions; flagrant violation of human rights. According to these causes, migratory movements are grouped into voluntary movements (consequences of economic factors) and forced movements.

An analysis of the migration phenomenon has revealed the outline of certain modernization trends for the phenomenon [3]:

a) globalization and migration are intertwined, influencing each other, generating the multipolarity of the areas of interest for migrants, diversification of the origin, destinations and compositions of the migration flows;

b) at international level, the migration from the developing countries to the developed ones has become dominant (urban centers);

c) the increase of illegal migration;

d) the increase in the share of women in global migration flows;

e) the emergence of the phenomenon of "selective migration" - the share of highly skilled 


\begin{abstract}
"Mircea cel Batran" Naval Academy Scientific Bulletin, Volume XIX - 2016 - Issue 1
Published by "Mircea cel Batran" Naval Academy Press, Constanta, Romania /I The journal is indexed in: PROQUEST / DOAJ / DRJI / JOURNAL INDEX / I2OR / SCIENCE LIBRARY INDEX / Google Scholar / Crossref /

Academic Keys / ROAD Open Access / OAJI / Academic Resources / Scientific Indexing Services / SCIPIO
\end{abstract}

labor in migration flows oriented towards developed countries has grown;

f) we can speak of mass migration of a contradictory evolution (growth alternates with periods of stagnation);

g) the migration and status of the actors involved vary considerably with time and space;

h) migration has become an important source of population growth, economic growth, productivity and even reduction of the level of poverty in the world.

\section{DELIMITATIONS IN TERMINOLOGY: IMMIGRANT I EMIGRANT - REFUGEE - ASYLUM SEEKER}

Any refugee is an immigrant, but not every immigrant is a refugee. Migrants represent a broader category of people who, for various reasons, move from one country to another; they generally have different reasons for leaving their country to go to another country.

Refugees are people who leave the area where armed conflict or persecutions are carried out by governments or local authority. Basically, in the case of refugees, the reasons are related to persecution and conflict. Migrants choose to leave their home for a better life; economic migrants seek a better job, a better life, while refugees leave their country to save their lives. This distinction is essential as refugees have no choice: if it were possible, they would remain in their home countries, they do not stay because their lives are in danger.

Seeking refuge is provisional, considering the semantic nature of the word [2]; but to use this word in relation to the wave of migrant people who have entered Europe lately appears to be wrong. These people aim to reach a certain country, especially Germany, the UK, the Scandinavian countries or Switzerland, in order to remain there permanently and never return to their country.

Refugees are protected under the provisions of the United Nations Convention on the status of refugees in 1951 [4], to which Romania adhered by Law no. 46/1991 [5]. Under the Convention, a refugee is a person who, as a result of events occurring before 1 January 1951 and some founded fear of being persecuted for reasons of race, religion, nationality, membership in a particular social group, or for their political opinion, is outside the country of their nationality, and cannot or, owing to such fear, does not want the protection of that country [4]. They try to escape from the power of their own government or from a new power organization locally constituted, stopping, for a period of time, any legal connection with their own state. In connection to this, the doctrine set forth a fundamental problem specific to the status of the refugee: generally, they do not go far away from their home or country of origin. Studies have shown that refugees from the path of a flood, fire or earthquake do not go farther than $500 \mathrm{~km}$ away; political refugees do not move farther than 2000 $\mathrm{km}$ from their country.

The quality of refugee shall cease in the following cases: if they ask again and voluntarily the protection of the state to which they belong as citizens; if, after losing citizenship, they regain it voluntarily; if they acquire another citizenship and enjoy the protection of the country whose citizenship they have acquired; if they return, voluntarily, to the country which they left.

Emigrants constitute the category of people who choose to move, not because of direct threats of persecution or death, but for a different standard of living by finding a job, even for education, family unification etc. Unlike refugees, who can not safely repatriate, emigrants may return to their countries, continuing to receive protection from their governments.

At the level of the European Union there are a number of regulations on refugees. One of these is Directive 2011/95/EU of the European Parliament and of the Council [6] on the standards for the conditions that must be met by third country nationals or stateless persons in order to benefit from international protection, for a consistent status for refugees or for persons eligible for subsidiary protection and the content of the protection granted. The Directive is without prejudice to the Protocol on the right to asylum for third country nationals of the European Union member states, annexed to the Treaty on the European Union (TEU) and Treaty on the Functioning of the European Union (TFEU).

The Directive defines in Article 2 a series of terms: - "International protection" means the status of refugee and the status conferred by subsidiary protection (Article 2 letter a);

- "Refugee" means any third-country nationals who, following a well-founded fear of being persecuted for reasons of race, religion, nationality, political opinion or membership to a particular social group, are outside the country of their nationality, and who are unable or, owing to such fear, unwilling to request the protection of that country, or any stateless persons who, for the reasons above, are outside the country of former habitual residence, and are unable or, owing to such fear, unwilling to return to that country (letter d);

- "Refugee status" means the recognition by a member state of the quality of refugee of any third country national or stateless person (letter e).

The main objective of the Directive is, on the one hand, to ensure that all member states apply 


\begin{abstract}
"Mircea cel Batran" Naval Academy Scientific Bulletin, Volume XIX - 2016 - Issue 1
Published by "Mircea cel Batran" Naval Academy Press, Constanta, Romania /I The journal is indexed in: PROQUEST / DOAJ / DRJI / JOURNAL INDEX / I2OR / SCIENCE LIBRARY INDEX / Google Scholar / Crossref /

Academic Keys / ROAD Open Access / OAJI / Academic Resources / Scientific Indexing Services / SCIPIO
\end{abstract}

common criteria for the identification of the persons genuinely in need of international protection and, on the other hand, to ensure a minimum level of benefits to those persons in all member states. The directive motivates, at point 13 , that the rules concerning the recognition and content of the status of refugee and of the subsidiary protection should help to limit the secondary movements of applicants for international protection between member states, where such movement is purely caused by differences between the legal frameworks of the member states.

Another important document is Regulation (EU) no. 604/2013 of the European Parliament and of the Council [7] establishing the criteria and mechanisms to determine the member state responsible for examining an application for international protection presented in one of the member states by a third-country national or a stateless person.

Member states shall examine any application for international protection made by a third-country national or a stateless person on the territory of any of them, including at the border or in transit zones. The regulation establishes the principle that a single member state is responsible for examining an application for international protection. The goal is to avoid a situation in which the applicants for international protection are sent from one country to another, and also to avoid abusing this system by the introduction of more applications for asylum by one person. The document defines objective and prioritized criteria in order to establish the responsible member state for each application. If no member state can be designated on the basis of the criteria established, the first member state in which the application for international protection has been presented is responsible for its assessment. It was thus necessary to introduce common criteria to recognize the refugee status of asylum seekers in Article 1 of the Geneva Convention.

The refugee status and the right to asylum are sometimes confused in the legal doctrine, not knowing the regulation of the applicable legal regime. In practice, it is difficult to make the distinction due to the fact that both institutions aim to ensure adequate protection for people who can no longer benefit from the protection of their state of origin [8].

One finding is that, unlike the refugee, the asylum seeker is not defined by any Romanian law [9]. The doctrine assessed that asylum seekers are foreigners (foreign citizens or stateless persons) who, in their country of origin, are subjected to persecution for their political, democratic or humanitarian activities, and who seek refuge in another state [10]. Another opinion [11] states that the asylum seeker is a natural person who, in their state of origin, is prosecuted or persecuted for activities in favor of humanity, progress and peace. Asylum is granted only to those wanted for political activities, not for common law offenses.

The asylum seeker is the natural entity that has been granted asylum, as provided by international legal instruments and internal normative acts. After granting the asylum, the state will not allow the asylum seeker to be involved in activities contrary to the purposes and principles of the UN. Asylum seekers have rights and can assume the obligations of any foreigner (foreigner or stateless) and can not be extradited.

\section{THE PRIORITIES OF THE EUROPEAN AGENDA ON MIGRATION. DEGREE OF APPLICABILITY}

The challenges presented by globalization, and its overlapping with trends towards regionalization and fragmentation, have caused multiple tensions and risk factors at international level, that have resulted in the immediate intensification of the contemporary migration phenomenon [1].

The main acceleration of the phenomenon was glimpsed in early 2011, with the outbreak of the war in Syria, making it the most significant factor of resettlement worldwide.

In 2014, according to a Report of the UN High Commissioner for Refugees (UNHCR) [12], on average 42.500 people daily became refugees, asylum seekers and internally displaced persons, corresponding to a fourfold increase of these figures in just four years. Thus, 59.5 million people were forcibly displaced at the end of 2014, compared with 51.2 million in the previous year and 37.5 million ten years ago. This level, compared to 2013, represents the highest increase ever recorded in a single year. Worldwide, one in 122 people is a refugee, internally displaced or seeking asylum. If it were the population of a country, the figure of 59.5 million would represent the 24th most populous country in the world. The UNHCR report shows that, in more and more regions, the number of refugees and internally displaced persons is increasing.

Delays in drawing up a general framework on migration and asylum and deferring the implementation of a system to redistribute immigrants caught the European Union completely unprepared before the largest wave of refugees since the end of World War II [13].

The Declaration of the European Council of 23 April 2015 [14] and the following Resolution of the European Parliament emphasized the need for 


\begin{abstract}
"Mircea cel Batran" Naval Academy Scientific Bulletin, Volume XIX - 2016 - Issue 1
Published by "Mircea cel Batran" Naval Academy Press, Constanta, Romania // The journal is indexed in: PROQUEST / DOAJ / DRJI / JOURNAL INDEX / I2OR / SCIENCE LIBRARY INDEX / Google Scholar / Crossref /

Academic Keys / ROAD Open Access / OAJI / Academic Resources / Scientific Indexing Services / SCIPIO
\end{abstract}

adopting urgent measures to save human lives, and also to intensify EU actions.

On 13 May 2015 the European Commission adopted a new European Agenda on Migration [15]. Through it, the Union proposes immediate measures needed to meet the current challenges of migration, as well as medium and long-term initiatives to be taken to provide structural solutions for a better management of migration in all its aspects [16].

In practical terms, managing the migration issue requires a dual perspective, as it implies an internal dimension, resulting from the joint responsibility of member states, and also an external dimension, managed in cooperation with non-EU countries, countries of transit and origin of immigrants.

In this respect, the global perspective proposed by the Agenda aims to deliver efficient results that can not be done without the use of all available policies and instruments, and even by combining internal and external policies of the EU member states. All parties involved: member states, EU institutions, international organizations, civil society, local authorities and third countries must work together so that the European policy on migration meets its goals.

One opinion considers that the migration policy will be successful provided it is supported by effective integration policy. Competence in this area lies primarily with the member states, but the European Union can support the actions taken by national governments, local authorities, and civil society initiatives.

The common policy of the Union concerning asylum, immigration, visas and external border controls is based on Title $V$ (Area of freedom, security and justice) of the Treaty on the Functioning of the European Union (TFEU).

Within the Agenda, four major directions of action were proposed:

1. To reduce the factors encouraging illegal migration, with a focus on addressing the fundamental causes of illegal migration from third countries and a better implementation of return policies;

2. To save lives and secure external borders through better management of external borders and streamline border procedures;

3. To strengthen the migration and asylum common policy;

4. To develop a new policy for legal migration, given the future demographic challenges faced by the EU.

Once implemented, these actions will give the EU a migration policy that is fair, solid and realistic, which respects the right to seek asylum, to answer humanitarian challenges, drawing a clear
European framework for a common policy on migration and withstanding the test of time [15]. In a press release [17], the Deputy High Commissioner for Protection of the UNHCR welcomed the proposal of the European Commission, announced on May 13th regarding the thousands of refugees and migrants arriving in Europe across the Mediterranean: "The EU proposals represent a great achievement concerning the management of migration and refugee flows" [...] "UNHCR is ready to continue to give all necessary support to EU member states to transpose these objectives into reality". Also, the UN High Commissioner for refugees, António Guterres, stated: "We are witnessing a paradigm shift, of an uncontrolled landslide into an era in which the magnitude of the global phenomenon of forced displacement, as well as the necessary response are clearly beyond any values and necessities ever recorded in this respect" .

The implementation of the EU Agenda on Migration is gradually done by adopting sets of measures by the European Commission. The first of these was held on 27 May 2015, comprising measures that were structured in three directions: legal migration, provisional measures in the resettlement of persons in need of international protection and strengthening the operational capacity (search and rescue) of FRONTEX.

A second set of measures, adopted on 9 September 2015, includes measures regarding: the return policy, the list of safe countries of origin, the EU emergency trust fund for Africa, the system of relocation of refugees, funding for migration and security, the balance between responsibility and solidarity on the issue of migration.

On 15 December 2015, the European Commission presented a third set of measures aimed at strengthening external borders. As such, there are considered: the security of EU border, the effective management of migration and improvement of EU internal security. Within this set of measures, the main document was the proposal for a Regulation establishing an Agency for Border and Coast Guard which strengthens the role of the European Agency in the management of external borders of the European Union.

At European level, the debates continued on how to strengthen the common policy for migration and asylum. The European Commissioner for Refugees, Dimitris Avramopoulos, admitted in the European Parliament debate on the EU-Turkey agreement that "Europe can not be transformed into a fortress and that such a fortress would not be able to keep out refugees in the term long anyway". The President of the European Council, 


\section{"Mircea cel Batran" Naval Academy Scientific Bulletin, Volume XIX - 2016 - Issue 1 \\ Published by "Mircea cel Batran" Naval Academy Press, Constanta, Romania /I The journal is indexed in: PROQUEST / DOAJ / DRJI / JOURNAL INDEX / I2OR / SCIENCE LIBRARY INDEX / Google Scholar / Crossref / \\ Academic Keys / ROAD Open Access / OAJI / Academic Resources / Scientific Indexing Services / SCIPIO}

Donald Tusk, declared that the voluntary assumption of refugees by the member states would be required, but this should not be the only solution: "It would be dangerous because a sharing of refugees among EU states could increase illegal migration towards Europe".

On 7 March 2016, Turkey agreed to accept the prompt return of all migrants who do not need international protection and who cross the border from Turkey to Greece, and take all migrants in an irregular situation being intercepted in Turkish territorial waters.

At the European Council meeting in Brussels on 18 March 2016, Turkey and the European Union reaffirmed their commitment to implement their joint action plan activated on 29 November 2015 [18]. It was the third meeting (after November 2015) dedicated to expanding the relations between Turkey and the EU, as well as addressing the migration crisis.

In this regard, it was decided to end illegal migration from Turkey to the $\mathrm{EU}$, and also to eliminate "the business model" used by people who illegally place migrants. The EU-Turkey agreement on migration, signed 18 March 2016 in Brussels, includes unusual and controversial measures, the most significant being the return to Turkey of all migrants leaving the country in the direction of Greece and taking over by the states of the community block of an equivalent number the migrants directly from Turkey. The agreement between the $28 \mathrm{EU}$ member states and Turkey was unanimously adopted and entered into force with March $20^{\text {th }}$. Instead, Turkey receives aid and certain political concessions.

The central idea of the agreement - sending back to Turkey all illegal migrants who reach the Greek islands - is the most controversial one. UN High Commissioner for Refugees (UNHCR) will participate in the program, but in an uncomfortable position in relation to the agreement provisions. The UN has warned that it is necessary to consolidate the capacity of Greece to assess asylum applications and emphasized that the implementation of the agreement is "crucial". Basically, the agreement with Turkey means that Greece must now rapidly develop, with European support, its capabilities for analyzing asylum applications and operating expulsions. The European Council President Donald Tusk assured that the agreement "excludes any collective expulsions".

A report by the International Organization for Migration (IOM), published only 10 days before the implementation of the agreement, shows that in the last week, only 1.578 refugees arrived in Greece, representing a decrease of $70 \%$. In the same period, 3.421 people arrived on the Italian coasts, however, showing that Italy takes the place of Greece as a main destination. In the first quarter of 2016, 18.357 immigrants arrived in Italy came from Libya, Eritrea, Sudan, Somalia and other African countries, according to the IOM.

The illegal migration across the Mediterranean Sea towards Italy increased as a result of the agreement reached by the European Union (EU) with Turkey in order to close the migratory route through Greece [19]. The European Council President, Donald Tusk, said on 13 April 2016 that the EU urgently needs to increase cooperation with Italy and Malta, also affected by the new situation, in order to prevent an aggravation of the crisis.

The High Representative of the Union for Foreign Affairs and Security Policy presented some proposals concerning any operations carried out under the European Security and Defense Policy (PASC) for identification, capture and systematic destruction of ships used by persons placing illegal migrants. Such actions can be carried out under international law.

The Joint Operational Team Mare (JOT Mare) recently set up within Europol, has defined the directions of action and has established a single contact point for inter-agency cooperation concerning the illegal introduction of migrants. It requested the cooptation of the European Agency for Maritime Safety, of the European Fisheries Control Agency, and of Eurojust. In this endeavor, Frontex and Europol elaborate profiles of ships that could be used by persons placing illegal migrants, targeting patterns to identify potential ships and monitor their movement. Europol will also identify the illegal content on the Internet used by individuals illegally placing migrants to attract migrants and refugees and will request its removal.

Based on the European Agenda on Migration, the $E U$ will use its instruments to manage the current problem faced by the member states in the forefront of migration flows.

One solution could be the new "outbreak" approach of the European Commission, which involves close field collaboration between the European Asylum Support Office, Frontex and Europol with the frontline member states, with a stated goal of shortly identifying, registering and fingerprinting immigrants. Asylum seekers will be immediately directed to an asylum procedure. For people who do not need protection, member states will enjoy the assistance of Frontex regarding the return of migrants in an illegal situation. Europol and Eurojust will assist host member states in investigations that might dismantle networks that illegally place migrants and of migrant traffickers. 


\begin{abstract}
"Mircea cel Batran" Naval Academy Scientific Bulletin, Volume XIX - 2016 - Issue 1
Published by "Mircea cel Batran" Naval Academy Press, Constanta, Romania /I The journal is indexed in: PROQUEST / DOAJ / DRJI / JOURNAL INDEX / I2OR / SCIENCE LIBRARY INDEX / Google Scholar / Crossref /

Academic Keys / ROAD Open Access / OAJI / Academic Resources / Scientific Indexing Services / SCIPIO
\end{abstract}

The Commission will mobilize as emergency funding an additional 60 million Euro, which will support the reception capacity, offering healthcare to migrants in the member states subject to particular pressure. In this respect, member states may use funds available under the Fund for asylum, migration and integration. Another possibility for countries particularly affected by an influx of migrants and asylum seekers is provided by the European Civil Protection Mechanism.

\title{
CONCLUSIONS
}

The efficient settlement of the migration crisis requires major changes in terms of the EU policy on migration, as it is necessary to ensure strong borders, fair procedures and a system able to anticipate problems. Attempts are made to create a unitary, accurate framework, to encompass the legal ways to enter the EU (through the efficient visa and asylum systems) in order to reduce factors that generate the illegal entry and residence, a framework that would also contribute to an increase in the security of European borders and the safety of migration flows. Achieving this goal concerns also the Integrated Border Management, and an increase in the efficiency of institutions such as Frontex, Europol, Eurosur (European Border Surveillance System), Cepol (European Police College), EBGT (European Border Guard Teams).

The membership in the European Union means, for Romania, both exercising the rights that accompany it, and also assuming the obligations involved. In the current refugee crisis, Romania must be in solidarity with other member states and actively participate in the effective management of the situation.

The European Union legislation, adopted and accepted by all member states, sets out its commitment to promote and protect human rights and human dignity, which is why the Union has given countless guarantees that it will offer international protection [20] to those in need. It also provides the solidarity principle, the member states having a duty to contribute to finding and implementing appropriate solutions for managing possible crises. Combining both internal and external policies, the EU Agenda on Migration offers an overall approach based on trust and solidarity between member states and EU institutions. There are applied new solutions, comprehensive approaches, seeking to effectively use the means and instruments the EU has at its disposal.

For the moment, granting international protection and refugee status represents only a crisis solution, a temporary one; the Union actions will be focused on the real cause of the waves of refugees, and not only on the effects. However, currently, the European Union and, therefore, all member states, must urgently implement measures to considerably reduce the number of refugees reaching the continent. EU actions should be extended beyond its borders, by strengthening cooperation with its global partners and by promoting legal migration arrangements.

\section{BIBLIOGRAPHY:}

[1] Bogdan Budeanu, Consideratii privind migratia ilegala, in GeoPolitical Magazine, issue 62 (4)/2015, pp.81-87.

[2] Dumitru Codita, Gabriela Petre, Fenomenul migrationist si statutul actual al refugiatilor, in GeoPolitical Magazine, issue 62 (4)/2015, pp.43-59.

[3]The World Migration Report 2015 - Migrants and Cities: New Partnerships to Manage Mobility, International Organization for Migration, Geneva, (on line), available at http://publications.iom.int/system/files/wmr2015_en.pdf, accessed on 12 March, 2016; see also Vasile Nazare, Migratia internationala si securitatea europeana. Politica UE privind migratia, in GeoPolitical Magazine, issue 62 (4)/2015, pp.36-42.

[4] UN Convention on the status of refugees, signed at Geneva on 28 July 1951.

[5] Law no. 46/1991 published in the Official Gazette issue 148/17 July 1991. Under the same law, Romania has also adhered to the Protocol regarding the status of refugees (New York, 31 January 1967).

[6] Directive 2011/95/UE of the European Parliament and Council of 13 December 2011, published in the Official Journal of the European Union L 337/9, abrogated Directive 2004/83/CE of the Council.

[7] Regulation (EU) no. 604/2013 of the European Parliament and of the Council of 26 June 2013, published in the Official Journal of the European Union L 180/31, abrogated Council Regulation no. 343/2003.

[8] Mihai Delcea, Protecţia juridică a refugiaţilor în dreptul internaţional, Presa Univesitară Română PH, Timişoara, 2002, p.82.

[9] Gheorghe Iancu, Vlad lancu, Dreptul de azil - Privire comparativa cu statutul juridic al refugiatului, edition revised and completed, Universul Juridic PH, Bucharest, 2015, p.38.

[10] Tudor Draganu, Drept constitutional si institutii politice. Tratat elementar, vol.I, Lumina Lex PH, Bucharest, 1998, p.153.

[11] Ioan Muraru, Drept constitutional si institutii politice, Lumina Lex PH, Bucharest, 2001, p.137. 
"Mircea cel Batran" Naval Academy Scientific Bulletin, Volume XIX - 2016 - Issue 1

Published by "Mircea cel Batran" Naval Academy Press, Constanta, Romania // The journal is indexed in:

PROQUEST / DOAJ / DRJI / JOURNAL INDEX / I2OR / SCIENCE LIBRARY INDEX / Google Scholar / Crossref /

Academic Keys I ROAD Open Access / OAJI / Academic Resources / Scientific Indexing Services / SCIPIO

[12] Asylum Trends 2014 - Report Tendinte Globale privind strămutarea fortată în 2014, the UN High Commissioner for Refugees, 18 May 2015.

[13] Criza mediteraneană şi criza refugiaţilor: angajamentul României faţă de Uniune şi angajamentul Uniunii faţă de drepturile omului, [on line] available at: https://newsint.ro/global-news/romania/criza-mediteraneanasi-criza-refugiatilor-angajamentul-romaniei-fata-de-uniune-si-angajamentul-uniunii-fata-de-drepturile-omului/

[14] European Council, Press-releases, http://www.consilium.europa.eu/ro/press/press-releases/2015/04/23special-euco-statement/ accessed on 15 March 2016.

[15] Communication from the Commission to the European Parliament, the Council, the European Economic and Social Committee and the Committee of the Regions - A European Agenda on Migration, COM (2015) 240 final , Brussels,available at: http://ec.europa.eu/lietuva/documents/power_pointai/communication on the european agenda on migration en.pdf, accessed on 12 March $201 \overline{6}$.

[16] Also see the website of Romanian Ministry of Foreign Affairs: http://www.mae.ro/

[17] UNHCR, Press-releases, Geneva, 13 May 2015, http://www.unhcr-centraleurope.org/ro/stiri/2015/unhcrsaluta-agenda-ue-pentru-migratie-cerand-adoptarea-de-urgenta-a-acestui-plan-inovator.html, accessed on 15 March 2016.

[18] European Council, EU - Turkey Statement, Press-releases, 18 March 2016, available at: http://www.consilium.europa.eu/ro/press/press-releases/2016/03/18-eu-turkey-statement/, accessed on 29 March 2016.

[19] Angela Sârbu, Acordul UE-Turcia a înrăutatit criza migratiei în Italia (online), AGERPRES, 14 April 2016 , available at: http://www.agerpres.ro/externe/2016/04/14/, accessed on 15 April, 2016.

[20] Roswitha Petry, La situation juridique des migrants sans statut légal - Entre droit international des droits de l'homme et droit suisse des migrations, Thesis no. 855 from the Faculty of Law of the University of Geneva, Schulthess Médias Juridiques PH, Geneva, 2013, p.38. 